\title{
PENILAIAN BISNIS DAN ESTIMASI NILAI INTRINSIK PT. GARUDA INDONESIA (PERSERO), TBK SAAT IPO FEBRUARI 2011
}

\author{
Theresia Lesmana ${ }^{1}$; Yen Sun ${ }^{2}$ \\ Accounting and Finance Department, Faculty of Economics and Communication, BINUS University \\ Jln. K. H. Syahdan No. 9, Palmerah, Jakarta Barat, 11480 \\ 'tlesmana@binus.edu; ${ }^{2}$ ysun@binus.edu
}

\begin{abstract}
Business valuation is an activity to estimate the value of company. The writers chose PT. Garuda Indonesia (Persero), Tbk. as the research object because PT. Garuda Indonesia (Persero), Tbk. just did an IPO on February 11, 2011. Based on IPO result, it is known the shares of PT. Garuda Indonesia (Persero), Tbk is overvalued to the intrinsic value. Therefore, the writers are interested in writing the thesis with title "Business Valuation and Estimated Intrinsic Value of PT. Garuda Indonesia (Persero), Tbk when IPO on February 2011". Business valuation used SWOT analysis and Porter analysis to know the non-financial performance. While from financial terms used Free Operating Cash Flow to the Firm (FCFF) to estimate the intrinsic value. Based on the analysis, it is obtained intrinsic value of share than compared with IPO price. The analysis used data from company website which was secondary data so that all necessary data in the research is available and could be accessed by everyone. The research approach used qualitative approach, by not using the hypothesis, and the result of reseacrh is descriptive data in the form of a narrative essay. Based on SWOT and Porter analysis, the company has good non-financial performance and is worth for investment options. Based on FCFF analysis, value of PT. Garuda Indonesia (Persero), Tbk. shares is overvalued. The writers advised stakeholders to not only see from overalued of shares but also see the non-financial performance.
\end{abstract}

Keywords: overvalued, SWOT analysis, Porter analysis, Free Operating Cash Flow to the Firm (FCFF) analysis

\begin{abstract}
ABSTRAK
Penilaian bisnis merupakan suatu kegiatan untuk memperkirakan nilai dari suatu perusahaan. Penulis memilih PT. Garuda Indonesia (Persero), Tbk sebagai objek penelitian karena PT. Garuda Indonesia (Persero), Tbk tanggal 11 Februari 2011 baru saja melakukan IPO. Dari hasil IPO diketahui bahwa saham PT. Garuda Indonesia (Persero), Tbk bernilai overvalued terhadap nilai intrinsiknya. Hal ini yang mendasari penulis dalam membuat penulisan skripsi yang berjudul "Penilaian Bisnis dan Estimasi Nilai Intrinsik PT. Garuda Indonesia (Persero), Tbk Saat IPO Februari 2011'. Penilaian bisnis menggunakan analisis SWOT dan analisis Porter yang bertujuan untuk melihat kinerja sisi non-keuangan. Sedangkan dari segi keuangan digunakan analisis Free Operating Cash Flow To the Firm (FCFF) untuk melakukan estimasi nilai intrinsik. Dari hasil analisis tersebut diperoleh nilai intrinsik saham yang kemudian dibandingkan dengan harga IPO. Analisis yang dilakukan menggunakan data dari situs perusahaan yang merupakan data sekunder sehingga semua data yang diperlukan dalam proses penelitian telah tersedia secara umum dan dapat diakses oleh siapa saja. Pendekatan penelitian yang digunakan adalah pendekatan kualitatif, dengan tidak menggunakan hipotesis dan hasil penelitian merupakan data deskriptif yang berupa karangan naratif dari analisis yang dilakukan.Hasil penelitian menunjukkan bahwa berdasarkan analisis SWOT dan analisis Porter, perusahaan memiliki segi non-keuangan yang baik dan layak untuk pilihan investasi. Berdasarkan analisis FCFF, nilai saham PT. Garuda Indonesia (Persero), Tbk bernilai overvalued. Peneliti memberikan saran kepada investor untuk tidak hanya melihat sisi saham yang overvalued tetapi juga dari segi non-keuangannya.
\end{abstract}

Kata kunci: overvalued, analisis SWOT, analisis Porter, analisis Free Operating Cash Flow To the Firm $(F C F F)$ 


\section{PENDAHULUAN}

Dalam kehidupan sehari-hari, tidak dapat dilepaskan dari kegiatan bisnis dalam bentuk apapun. Zaman dahulu manusia sudah mengenal bisnis yang masih sederhana yang disebut dengan barter. Seiring dengan berjalannya waktu dan pesatnya teknologi, bisnis menjadi lebih kompleks, sebagai contoh adalah bisnis yang dilakukan perusahaan. Perusahaan mengolah bahan baku menjadi produk yang berguna bagi konsumennya, melakukan jual beli kepada konsumen dan supplier yang kemudian memperoleh laba.

Di era globalisasi sekarang ini, semakin banyak berdiri perusahaan yang menyebabkan semakin terbukanya pasar nasional maupun internasional, baik perusahaan kecil, menengah, ataupun perusahaan besar, dan semuanya melakukan bisnis. Semakin banyak perusahaan, perkembangan ekonomi dan pesatnya sistem informasi dan teknologi mengakibatkan perusahaan tersebut mengalami persaingan bisnis yang cukup ketat.

Untuk menghadapi persaingan bisnis yang ketat tersebut, para pelaku bisnis harus jeli dalam melihat kekuatan dan peluang dalam upaya mengatasi kekurangan dan hambatan yang ada di dalam perusahaan sehingga mampu bertahan dalam persaingan di dunia bisnis. Hal tersebut dilakukan karena perusahaan tidak hanya mendirikan perusahaan untuk jangka pendek saja melainkan berharap untuk dapat mempertahankan kelangsungan hidup selama mungkin.

Salah satu cara untuk bertahan dalam persaingan bisnis tersebut, perusahaan dapat melakukan ekspansi usaha. Dalam melakukan ekspansi usaha, perusahaan pasti membutuhkan dana. Alternatif sumber pendanaan dapat diperoleh dari internal maupun dari eksternal perusahaan. Pendanaan yang berasal dari internal perusahaan dapat berasal dari laba ditahan, cadangan penyusutan, maupun dana yang langsung berasal dari pemilik. Sedangkan sumber pendanaan eksternal dapat berupa utang dagang dan utang bank, atau dengan menggunakan sarana pendanaan usaha melalui pasar modal yang berupa penjualan obligasi dan pendanaan dalam bentuk saham.

Setiap perusahaan yang ingin mendapatkan sumber dana melalui penerbitan saham harus melakukan penawaran umum (Initial Public Offering) kepada masyarakat terlebih dahulu atau sering dikenal dengan istilah go public. Perusahaan yang go public berarti perusahaan tersebut menawarkan kepemilikan atas perusahaan untuk dimiliki oleh masyarakat luas, khususnya investor dan selanjutnya dapat mencatatkan sahamnya di bursa efek.

Dalam melakukan IPO, perusahaan harus menerbitkan prospektus sebelum mencatatkan sahamnya di bursa efek. Di dalam prospektus terdapat informasi sehubungan dengan penawaran umum dengan tujuan agar investor membeli saham. Informasi dalam prospektus memberikan gambaran tentang kondisi, propek ekonomi, rencana investasi, ramalan laba, dan dividen yang akan dijadikan dasar dalam pembuatan keputusan.

Investor yang akan menanamkan modalnya ke perusahaan yang akan go public, sebaiknya melakukan penilaian terhadap perusahaan tersebut secara menyeluruh baik dari segi non-keuangan maupun segi keuangan perusahaan sebelum membeli saham. Hal tersebut dikarenakan adanya kecenderungan terhadap harga saham yang undervalued pada saat IPO. Karena pada saat IPO, IPO dijadikan wadah untuk menarik perhatian investor agar mau menanamkan modalnya sehingga informasi yang ada dalam prospektus dibuat semenarik mungkin dan dikhawatirkan investor akan mengalami kerugian setelah IPO akibat harga saham yang overvalued. 
Untuk mencegah hal itu, maka sebaiknya dilakukan penilaian bisnis secara menyeluruh dari segi non-keuangan dan segi keuangan. Penilaian bisnis tersebut diharapkan agar para investor tidak salah dalam mengambil keputusan investasi.

Dalam penelitian ini, penulis memilih PT. Garuda Indonesia (Persero), Tbk. sebagai objek penelitian karena perusahaan penerbangan negara tersebut baru saja melakukan penawaran umum pada tanggal 2, 4, 7, dan 8 Februari 2011. Penawaran umum yang dilakukan PT. Garuda Indonesia tersebut bertujuan untuk melakukan ekspansi usahanya. Selain itu, diduga pula bahwa harga saham PT. Garuda Indonesia (Persero), Tbk. mengalami overvalued setelah penawaran umum dilakukan. Namun, hal tersebut bukan salah satu faktor bagi investor untuk membuat kesimpulan bahwa berinvestasi PT. Garuda Indonesia (Persero), Tbk. tidak memberikan keuntungan. Sehingga, perlu dilakukan pula penilaian bisnis secara menyeluruh tidak hanya dari segi nilai saham, tetapi juga dari segi non-keuangan untuk melihat prospek ke depan perusahaan tersebut.

\section{Studi Pustaka}

Penelitian mengenai penilaian bisnis sudah banyak dilakukan. Penilaian bisnis tersebut dilakukan dengan beraneka ragam metode. Goldberg (2009) melakukan penelitian terhadap bisnis jalan tol yang dimiliki oleh Transurban Group. Penilaian tersebut menggunakan capital asset pricing model (CAPM) and the discounted cash flow (DCF) method. Tujuan dari penelitian tersebut ialah melihat pengaruh terhadap solvabilitas di masa yang akan datang. Dari penilaian bisnis diperoleh hasil bahwa berdasarkan laporan keuangan yang dihitung, jalan tol tersebut dinyatakan overvalued. Overvalued tersebut akan meningkatkan risiko kebangkrutan yang disebabkan adanya kelebihan pinjaman. Sebagai contoh, hanya ada uang kas sebesar 5\% di bank dari total kewajiban. Peneliti juga menuliskan referensi-referensi khusus untuk Transurban Group di dalam penelitiannya.

Fernandez (2007) melakukan penelitian terhadap penilaian bisnis dengan cash flow discounting. Penelitian tersebut bertujuan untuk menjawab pertanyaan apakah penilaian bisnis yang diakukan dengan menggunakan 10 metode dari discounted cash flow, yang terdiri atas free cash flow, equity cash flow, capital cash flow, adjusted present value, business's risk adjusted free cash flow and equity cash flow, risk-free rate-adjusted free cash flow and equity cash flow, economic profit, and economic value added memberikan nilai yang sama atau tidak. Penilaian bisnis tersebut dilakukan terhadap perusahaaan Toro, Inc.

Hasil yang diperoleh dari penelitian tersebut menyimpulkan bahwa penilaian bisnis dengan menggunakan 10 metode discounted cash flow selalu memberikan hasil yang sama. Penelitian tersebut juga menjelaskan sembilan teori (No-cost-of-leverage, Modigliani and Miller (1963), Myers (1974), Miller (1977), Miles and Ezzell (1980), Harris and Pringle (1985), Damodaran (1994), With-cost-ofleverage, dan Practitioners method) yang berbeda untuk melakukan penilaian bisnis. Hasil penilaian bisnis dari sembilan teori tersebut berbeda karena perhitungan value of tax shield (VTS). Dan dari sembilan teori, teori Modigliani dan Miller (1963) dan teori Myers (1974) yang memberikan hasil yang tidak konsisten.

\section{METODE PENELITIAN}

Jenis data yang digunakan dalam penelitian ini adalah jenis data kualitatif. Sedangkan sumber data yang digunakan berupa data sekunder yang berasal dari laporan tahunan PT. Garuda Indonesia (Persero), Tbk., pergerakan indeks harga saham gabungan, harga saham 5 perusahaan BUMN, seperti PT. Telkom, Tbk., PT Bank Mandiri, Tbk., PT. Bank Rakyat Indonesia, Tbk., PT. Perusahaan Gas Negara, Tbk., serta PT Bank Negara Indonesia, Tbk. 
Penelitian ini menggunakan tiga pendekatan yang terdiri dari pendekatan dari sisi nonkeuangan dan pendekatan dari sisi keuangan. Pendekatan dari sisi non keuangan, yaitu analisis SWOT dan analisis Porter, sedangkan dari sisi keuangan menggunakan metode present value of operating free cash flow (FCFF).

\section{HASIL DAN PEMBAHASAN}

\section{Penilaian Bisnis Menggunakan Analisis SWOT}

Mengacu pada Hunger \& Wheelen yang diterjemahkan oleh Agung (2003:193), definisi analisis SWOT, yaitu sebagai berikut:

"Analisis SWOT adalah analisis sistematis untuk mengidentifikasikan faktor-faktor kekuatan (strength), kelemahan (weakness) intern perusahaan serta peluang (opportunities) dan ancaman (threats) dalam lingkungan yang dihadapi perusahaan."

Dalam analisis SWOT atau analisis situasi akan dilihat faktor internal perusahaan seperti kekuatan dan kelemahan, serta faktor eksternal seperti peluang dan hambatan perusahaan yang dihadapi perusahaan dalam menciptakan keunggulan kompetitif untuk dapat bersaing di dalam lingkungan industri.

Penjabaran faktor-faktor tersebut adalah: pertama, strengths (kekuatan), yaitu segala sesuatu yang dimiliki oleh perusahaan seperti sumber daya, keterampilan, atau kelebihan lain yang memberikan keunggulan komparatif bagi perusahaan dibandingkan perusahaan lain. Kedua, weakness (kelemahan), ialah kekurangan atau keterbatasan dalam sumber daya yang dimiliki perusahaan yang menghambat kinerja efektif perusahaan dalam mencapai tujuan. Ketiga, opportunities (peluang), ialah situasi dan kondisi yang menguntungkan dalam lingkungan perusahaan. Keempat, threats (ancaman), ialah situasi dan kondisi yang tidak menguntungkan dalam lingkungan perusahaan.

Dengan mengidentifikasikan faktor-faktor tersebut, perusahaan dapat merumuskan strategi dalam menciptakan keunggulan kompetitif agar tidak kalah bersaing dengan perusahaan sejenis.

\section{Tahap Membuat Analisis SWOT}

Berdasarkan Hunger \& Wheelen yang diterjemahkan oleh Agung (2003), terdapat dua tahap dalam membuat analisis SWOT. Tahap tersebut ialah: pertama, tahap pengumpulan data, yaitu tahap mengumpulkan data yang berhubungan dengan perusahaan baik data eksternal maupun data internal perusahaan untuk menentukan kekuatan, kelemahan, peluang dan hambatan perusahaan. Data eksternal, yaitu data yang berasal dari lingkungan luar perusahaan yang terdiri dari: lingkungan eksternal mikro, data dari lingkungan eksternal mikro ini akan melihat keadaan seperti pasar, pesaing, pemasok, dan konsumen terhadap perusahaan; lingkungan eksternal makro, data dari lingkungan eksternal makro akan melihat keadaan seperti politik, ekonomi, sosial budaya, teknologi, maupun geologi terhadap perusahaan. Data internal, yaitu data yang berasal dari dalam perusahaan seperti laporan keuangan perusahaan, laporan kegiatan SDM, laporan kegiatan operasi, budaya perusahaan, nilai-nilai yang diyakini manajemen bahkan dari struktur organisasi perusahaan. Kedua, tahap analisis, yaitu tahap mengidentifikasikan kekuatan dan kelemahan yang merupakan faktor internal perusahaan serta peluang dan ancaman yang merupakan faktor eksternal perusahaan.

Setelah mengidentifikasi faktor-faktor tersebut, langkah berikutnya yaitu dengan merumuskan strategi yang dijalankan perusahaan sesuai dengan faktor internal dan faktor eksternal perusahaan. Strategi-strategi tersebut dirumuskan dengan menggunakan diagram SWOT. Diagram SWOT tersebut digambarkan dalam tabel seperti berikut. 
Tabel 1 Diagram SWOT

\begin{tabular}{|c|c|c|}
\hline External $\begin{array}{c}\text { Internal Fact } \\
\text { Factors (EFAS) }\end{array}$ & $\begin{array}{l}\text { STRENGTHS } \\
\text { (S) }\end{array}$ & $\begin{array}{l}\text { WEAKNESS } \\
\text { (W) }\end{array}$ \\
\hline OPPORTUNITIES (O) & SO Strategies & WO Strategies \\
\hline THREATS (T) & ST Strategies & WT Strategies \\
\hline
\end{tabular}

Keterangan Tabel:

SO strategies: strategi dengan menggunakan kekuatan untuk mengambil keuntungan dari peluang yang ada.

ST strategies: strategi dengan menggunakan kekuatan untuk mengatasi atau menghadapi ancaman yang dihadapi perusahaan.

WO strategies: strategi untuk mengambil keuntungan dari peluang yang ada untuk mengatasi kelemahan yang dimiliki perusahaan.

WT strategies: strategi untuk meminimalkan kelemahan dengan menghindari ancaman dari luar perusahaan.

\section{Penilaian Bisnis Menggunakan Analisis Porter}

Berdasarkan David Fred R. (terjemahan Surnadi D., 2009), pendekatan yang digunakan untuk mengembangkan strategi di dalam suatu industri tertentu dalam menghadapi persaingan industri dapat menggunakan Model Lima Kekuatan Porter (Porter's Five-Forces Model). Model ini dikembangkan oleh Michael E. Porter tahun 1980-an, yang memandang bahwa persaingan suatu industri dipandang sebagai perpaduan dari lima kekuatan yakni antara lain: pertama, persaingan antarperusahaan saingan, intensitas persaingan antarperusahaan dipengaruhi oleh beberapa faktor, seperti perusahaan pesaing yang lebih unggul dalam hal kemampuan melakukan inovasi produk dengan harga yang terjangkau, permintaan produk di industri tersebut menurun, dan mudahnya konsumen untuk beralih merek. Kedua, potensi masuknya pesaing baru, intensitas persaingan juga akan meningkat apabila perusahaan baru dengan mudah dapat masuk ke suatu industri tertentu. Kekuatan ini dipengaruhi dari besar kecilnya hambatan pesaing baru untuk masuk ke suatu industri. Makin kecil hambatan yang dihadapi pesaing baru, makin besar ancaman bagi perusahaan yang sudah ada. Sedangkan sebaliknya, makin besar hambatan yang dihadapi pesaing baru, makin kecil ancaman bagi perusahaan yang sudah ada. Ketiga, potensi pengembangan produk-produk pengganti, faktor-faktor yang dapat meningkatkan tekanan persaingan dari produk pengganti, yaitu seperti harga yang ditawarkan produk pengganti lebih rendah, produk pengganti yang juga memiliki pangsa pasar yang besar, atau mutu dari produk pengganti yang melebih produk sebelumnya. Keempat, daya tawar pemasok, kekuatan bersaing yang dipengaruhi oleh daya tawar pemasok akan makin bertambah ketika hanya ada sedikit jumlah pemasok, makin penting produk yang dipasok karena sedikitnya bahan mentah pengganti yang bagus, dan sebagainya. Kelima, daya tawar konsumen, faktor-faktor yang dapat memengaruhi daya tawar konsumen, misalnya mudahnya beralih ke produk pengganti dengan harga yang lebih murah, permintaan konsumen yang menurun, informasi yang dimiliki konsumen tentang produk, harga, dan biaya penjual. Berikut ini adalah gambar lima kekuatan Porter. 


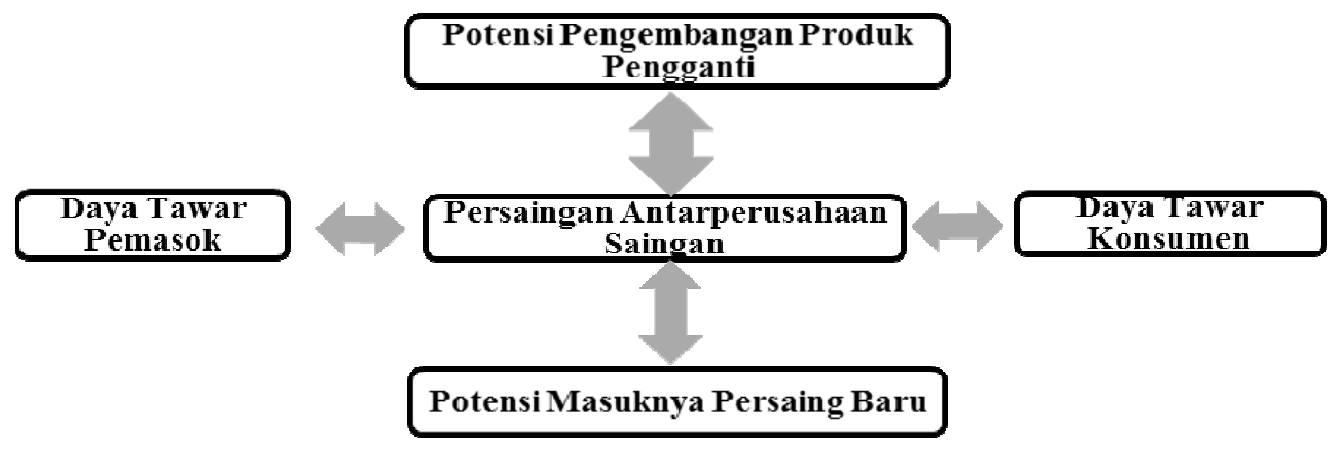

Gambar 1 Model Lima Kekuatan Porter

\section{Tahap Analisis Porter}

Mengacu kepada David Fred R. (terjemahan Surnadi D., 2009), terdapat tiga langkah dalam menggunakan Model Lima Kekuatan Porter. Tiga langkah tersebut ialah: mengidentifikasi berbagai aspek atau elemen penting dari setiap kekuatan yang memengaruhi perusahaan, evaluasi seberapa kuat dan penting setiap kekuatan tersebut bagi perusahaan, dan melakukan keputusan apakah elemenelemen dari masing kekuatan cukup untuk membuat perusahaan terjun ke industri baru atau tetap bertahan di industri yang dijalankan sekarang ini.

\section{Analisis Estimasi Nilai Intrinsik Menggunakan FCFF}

Mengacu pendapat Stowe, Robinson, Pinto, dan McLeavey (2007), FCFF ialah laba operasi perusahaan setelah pajak yang tersedia untuk seluruh penyandang modal perusahaan baik kreditur maupun pemegang saham. Mengacu kepada Brown dan Reilly (2009), tujuan dari penggunaan FCFF yaitu untuk menentukan nilai suatu ekuitas perusahaan setelah mengurangi jumlah dari nilai kewajiban perusahaan.

Untuk menghitung nilai intrinsik suatu saham, ada beberapa langkah perhitungan yang perlu dilakukan. Perhitungan tersebut akan diuraikan sebagai berikut.

\section{Weighted Average Cost of Capital (WACC)}

Modal merupakan segala sesuatu yang digunakan prusahaan untuk dapat melakukan proses produksi atau melakukan investasi. Modal tersebut dapat berupa utang, saham biasa dan saham preferen. Untuk memperoleh modal tersebut maka perusahaan harus mengeluarkan biaya yang disebut sebagai biaya modal.

Mengacu pendapat Sugiono (2008), biaya modal ialah biaya yang harus dikeluarkan oleh perusahaan sebagai tingkat pengembalian yang diharapkan investor atas investasi proyek untuk dapat mempertahankan nilai pasar sahamnya. Biaya modal itu sendiri terdiri dari biaya modal ekuitas dan biaya utang. Biaya modal ekuitas dan biaya utang tersebut akan dibahas masing-masing.

Setelah kedua komponen tersebut diketahui, maka biaya modal tersebut dapat dihitung ke dalam perhituangan WACC. Mengacu kepada Brigham dan Houston (terjemahan Yulianto, 2006), rata-rata tertimbang biaya modal (WACC) yaitu perhitungan biaya modal (cost of capital) perusahaan dengan memberi rata-rata tertimbang dari jenis-jenis modal yang digunakan oleh perusahaan untuk tetap menjaga persentase keseimbangan struktur permodalannya. 
Perhitungan WACC adalah sebagai berikut:

$$
\mathrm{WACC}=\left(\frac{\text { Total Debt }}{\text { Total Equtty }+ \text { Total Debt }} \times(k \mathrm{~d} X(1-T))+\left(k s \times \frac{\text { Total Equtty }}{\text { Total Equtty }+ \text { Total Debs }}\right)\right.
$$

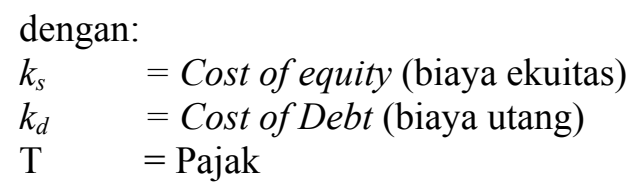

Biaya Ekuitas dan biaya utang tersebut dapat diuraikan sebagai berikut:

\section{Cost of Equity (Biaya Modal Ekuitas)}

Menurut Van Horne dan Wachowicz (terjemahan Fitriasari dan Kwary, 2001:122), definisi biaya modal ekuitas adalah tingkat pengembalian yang diminta atas investasi oleh para pemegang saham perusahaan. Metode yang dapat digunakan dalam perhitungan biaya modal ekuitas, yaitu dengan menggunakan perhitungan capital asset pricing model (CAPM). Mengacu kepada Brigham dan Houston (terjemahan Yulianto, 2006), CAPM ialah sebuah model yang menggambarkan hubungan antara risiko dengan tingkat pengembalian yang diharapkan.

Dalam CAPM, hal mendasar yang membedakan expected return (cost of equity) perusahaan satu dengan perusahaan yang lain adalah beta. Beta secara teoretis adalah ukuran dari tingkat risiko pasar.

Persamaan CAPM dapat dihitung dengan cara berikut:

$$
E(R)=E\left(R F R+\beta\left(R_{M}-R F R\right)\right.
$$

dengan:

$\mathrm{RFR}=$ Risk free rate $(B I$ Rate $)$

$\mathrm{R}_{M} \quad=$ Market rate of return (menggunakan IHSG per mingguan dari 2006-2010)

$\beta$ (Beta) $=$ Ukuran dari risiko pasar

\section{Risk Free Rate}

Mengacu pendapat Stowe, Robinson, Pinto, dan McLeavey (2007), risk free rate yaitu tingkat pengembalian minimun kepada investor akibat imbal balik dari investasi yang dilakukannya tanpa mempertimbangankan risiko keuangan perusahaan. Dalam penelitian ini, penulis meggunakan Bi rate sebagai risk free rate perusahaan. Mengacu kepada pendapat bank Indonesia, BI rate merupakan suku bunga yang mencerminkan kebijakan moneter yang ditetapkan oleh Bank Indonesia dan diumumkan kepada publik. BI rate tersebut digunakan oleh Bank Indonesia pada operasional moneter melalui pengelolaan likuiditas di pasar uang.

\section{Market Rate of Return}

Mengacu pendapat Stowe, Robinson, Pinto, dan McLeavey (2007), market rate of return yaitu tingkat pengembalian yang diharapkan terhadap portofolio pasar yang terjadi. Dalam penelitian ini, penulis menggunakan IHSG sebagai tingkat pengembalian pasar karena IHSG merupakan indikator utama yang menggambarkan pergerakan harga saham di pasar modal. 


\section{Beta}

Mengacu pendapat Brigham dan Houston (terjemahan Yulianto, 2006), beta ialah risiko yang terdapat dalam saham terhadap pasar saham yang mengukur sejauh mana tingkat pengembalian saham terhadap pasar. Berdasarkan pendapat Fakhruddin (2008), beta sebesar 1 artinya harga saham akan bergerak mengikuti pasar. Beta lebih dari 1, artinya harga saham lebih volatil/fluktuatif daripada pasar. Sedangkan beta yang kurang dari 1, artinya harga saham tidak sefluktuatif pasar.

\section{Cost of Debt (Biaya Utang)}

Menurut Van Horne dan Wachowicz (terjemahan Fitriasari dan Kwary, 2001:122), definisi biaya utang ialah sebagai berikut: biaya (modal) utang ialah tingkat pengembalian yang diminta atas investasi oleh para pemberi pinjaman ke perusahaan. Biaya utang setelah pajak digunakan untuk menghitung rata-rata tertimbang dari modal. Biaya utang setelah pajak merupakan tingkat bunga atas utang, $\mathrm{k}_{\mathrm{d}}$. Utang dapat diperoleh perusahaan melalui pinjaman dari lembaga pembiayaan seperti bank atau dengan menerbitkan obligasi.

Mengacu kepada Damodaran (2006), biaya utang dapat dihitung dengan menggunakan Damodaran Spreadsheet. Damodaran Spreadsheet yaitu tabel peringkat obligasi yang dipublikasikan oleh lembaga terpercaya yang menilai kemampuan dan kualitas sebuah obligasi dapat dilunasi oleh penerbit obligasi, kode peringkat tertinggi dari AAA sampai D.

Tabel 2 Peringkat Obligasi

Default Spreads for rating Classes: Early 2009

\begin{tabular}{lcc}
\hline Rating & Default Spread & Interest Rate of Bond \\
\hline AAA & $1.25 \%$ & $4.75 \%$ \\
AA & $1.75 \%$ & $5.25 \%$ \\
A+ & $2.25 \%$ & $5.75 \%$ \\
A & $2.50 \%$ & $6.00 \%$ \\
A- & $3.00 \%$ & $6.50 \%$ \\
BBB & $3.50 \%$ & $7.00 \%$ \\
BB & $4.25 \%$ & $7.75 \%$ \\
B+ & $5.00 \%$ & $8.50 \%$ \\
B & $6.00 \%$ & $9.50 \%$ \\
B- & $7.25 \%$ & $10.75 \%$ \\
CCC & $8.50 \%$ & $12.00 \%$ \\
CC & $10.00 \%$ & $13.50 \%$ \\
C & $12.00 \%$ & $15.50 \%$ \\
D & $15.00 \%$ & $18.50 \%$ \\
\hline
\end{tabular}

Kemudian perhitungan biaya utang (cost of debt) dapat dilakukan dengan rumus sebagai berikut:

Cost of debt $=$ Risk free rate + Default spread for country + Default spread for firm

dengan:

Risk free rate $=$ Tingkat bebas bunga $(\mathrm{BI}$ Rate $)$

Default spread for country $=$ Tingkat selisih risiko bagi negara

Default spread for firm $=$ Tingkat selisih risiko bagi perusahaan 


\section{Percentage of Sales Method}

Mengacu kepada Lane (2002), metode persentase penjualan ialah pendekatan dalam meramalkan keuangan perusahaan yang diasumsikan bahwa perkiraan akun-akun dalam neraca dan laporan laba rugi pada masa mendatang ditentukan dengan penjualan. Sehingga, sebelum melakukan perkiraan terhadap suatu akun tertentu, terlebih dahulu dilakukan peramalan penjualan. Rumus persentase penjualan tersebut dapat diformulasikan sebagai berikut:

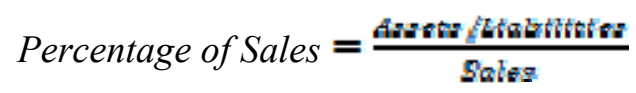

dengan:

Percentage of sales $=$ persentase penjualan

Assets/liabilities $=$ aktiva/ pasiva atau akun yang akan dipakai

Sales $=$ penjualan

Metode ini digunakan dalam menghitung forcasting sales untuk digunakan sebagai dasar dalam estimasi komponen FCFF. Dengan peramalan penjualan dengan penggunaan rumus Forecast pada Microsoft Excel.

\section{Perhitungan FCFF}

Setelah mengetahui hasil dari perhitungan WACC, maka selanjutnya dapat dihitung nilai FCFF menurut Damodaran (2006). FCFF dapat dihitung dengan cara:

\section{$F C F F=E B I T(1-T a x$ Rate $)+$ Depreciation Expense - Capital}

Expenditures - $\Delta$ in Non Cash Working Capital

dengan:

EBIT $(1-$ Tax Rate $)=$ Pendapatan setelah dikurangi pajak dan bunga

Depreciation Expense = Beban Penyusutan

Capital expenditur $=$ pengeluaran $/$ belanja modal

Change in non cash working capita $=$ perubahan modal kerja $(\mathrm{A} / \mathrm{R}+$ Inventory-A/P)

Setelah diketahui nilai dari free cash flow the firm, dapat dihitung nilai dari perusahaan tersebut, dengan cara:

$$
\text { Firm Value }=\frac{F C F F}{\text { WACC-g }}
$$

Jika value of the firm sudah diketahui, selanjutnya dapat menghitung nilai intrinsik harga saham perusahaan dan kemudian membandingkannya dengan market value apakah undervalued atau overvalued. Perhitungan nilai intrinsik dapat dijabarkan sebagai berikut:

$$
\text { Value of firm }=\text { Total eauitv }+ \text { total debt }
$$

Total equity $=$ Value of firm - total debt 


$$
\text { Intrinsik Value }=\frac{\text { Total equity }}{\text { Totalsaham yamg beredar }}
$$

Dari hasil nilai intrinsik yang diperoleh akan dibandingkan dengan nilai pasar. Jika estimasi nilai intrinsik lebih besar dari nilai pasar disebut dengan undervalued stock, sebaiknya saham tersebut dibeli. Apabila nilai intrinsik lebih kecil dari harga pasar atau disebut dengan overvalued stock, sebaiknya saham tersebut dijual.

\section{Hasil Analisis}

Berikut ini penilaian bisnis menggunakan analisis SWOT pada PT. Garuda Indonesia (PERSERO), Tbk.
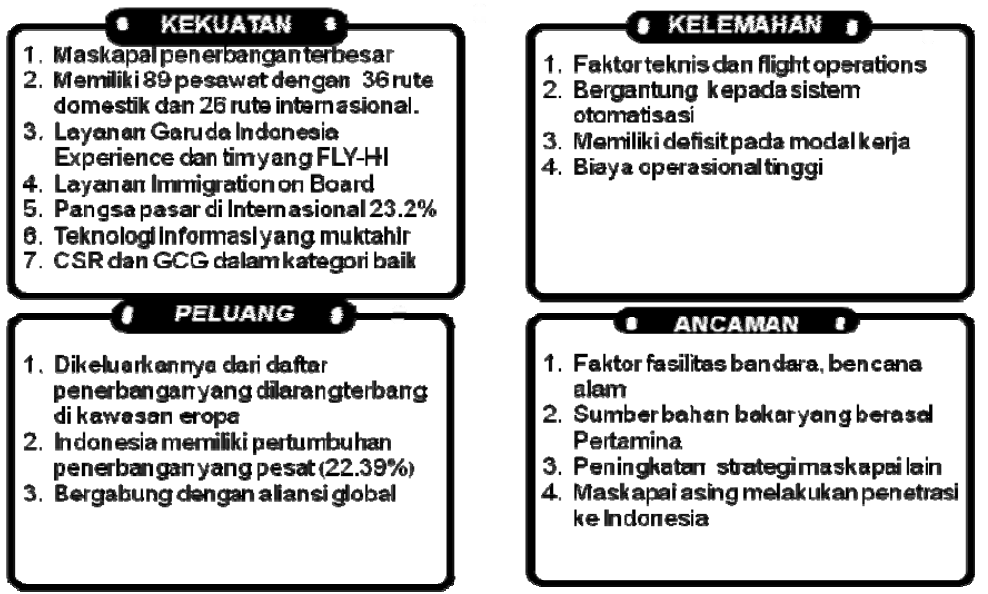

Gambar 2 Analisis SWOT pada PT. Garuda Indonesia (Persero), Tbk.

Sedangkan penilaian bisnis dengan menggunakan analisis Porter pada PT. Garuda Indonesia (Persero), Tbk. adalah sebagai berikut.

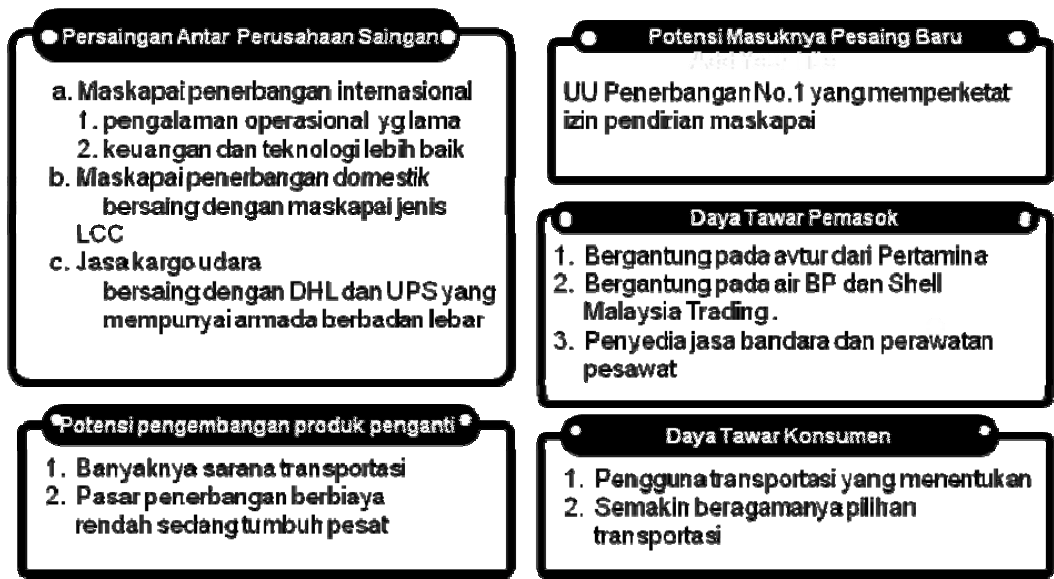

Gambar 3 Analisis Porter pada PT. Garuda Indonesia (Persero), Tbk. 


\section{Estimasi Nilai Intrinsik PT. Garuda Indonesia (Persero), Tbk.}

\section{Pertumbuhan Ekonomi Indonesia}

Tingkat pertumbuhan ekonomi Indonesia pada triwulan pertama 2011 yang diperoleh dari data BPS (Badan Pusat Statistik) yaitu sebesar 6,5\%. Oleh karena itu, tingkat economic growth Indonesia yang akan digunakan dalam penelitian ini sebesar $6,5 \%$. Penelitian menggunakan data historis lima tahun yaitu pada 2006 sampai 2010 dari 5 perusahaan BUMN yang mencatatkan sahamnya di bursa efek pada 2006-2010 untuk menghitung beta rata-rata yang akan digunakan dalam perhitungan CAPM. Perusahaan tersebut antara lain: PT. Telkom, Tbk. (TLKM); PT. Bank Mandiri, Tbk. (BMRI); PT. Bank Rakyat Indonesia, Tbk. (BBRI); PT. Perusahaan Gas Negara, Tbk. (PGAS); serta PT. Bank Negara Indonesia, Tbk. (BBNI).

Dalam perhitungan estimasi harga wajar saham Garuda akan digunakan pendekatan WACC. Perolehan hasil dari WACC didapat dari nilai tiap-tiap komponen biaya dari WACC tersebut, antara lain: biaya modal ekuitas $\left(\mathrm{k}_{\mathrm{s}}\right)$ dan biaya utang $\left(\mathrm{k}_{\mathrm{d}}\right)$. Biaya modal ekuitas $\left(\mathrm{k}_{\mathrm{s}}\right)$ tersebut dihitung dengan menggunakan CAPM, sedangkan biaya utang $\left(\mathrm{k}_{\mathrm{d}}\right)$ dihitung dengan menggunakan Damodaran Spreadsheet.

\section{Biaya Ekuitas (Cost of Equity)}

CAPM merupakan pendekatan yang bisa digunakan dalam perhitungan biaya ekuitas $\left(\mathrm{k}_{\mathrm{e}}\right)$. Data yang diperlukan untuk menghitung biaya ekuitas tersebut yaitu Indeks Harga Saham Gabungan (IHSG), risk free rate (BI rate), dan beta. Beta yang digunakan dalam penelitian ini diasumsikan sama dengan rata-rata beta industri BUMN, dimana, perusahaan BUMN yang diambil sebagai rata-rata industri ialah perusahaan BUMN yang mewakili perusahaan BUMN secara rata-rata dengan mengambil 5 perusahaan BUMN tertinggi dengan nilai kapitalisasi pasar terbesar per 29 Desember 2010. Perusahaan BUMN tersebut antara lain: PT. Telkom, Tbk. (TLKM); PT. Bank Mandiri, Tbk. (BMRI); PT. Bank Rakyat Indonesia, Tbk. (BBRI); PT. Perusahaan Gas Negara, Tbk. (PGAS); serta PT. Bank Negara Indonesia, Tbk. (BBNI).

Langkah pertama, penulis melakukan perhitungan tingkat pengembalian harga saham $\left(\mathrm{R}_{\mathrm{i}}\right)$, dan tingkat pengembalian pasar $\left(\mathrm{R}_{\mathrm{M}}\right)$ secara mingguan dari masing-masing 5 perusahaan BUMN tersebut. Tingkat pengembalian tersebut dihitung menggunakan fungsi natural logarithm (LN) dalam Microsoft Excel. Adapun perhitungan tingkat pengembalian tersebut ialah:

o Tingkat pengembalian harga saham TLKM 2 Januari 2006 $=\mathrm{LN}(6200 / 6100)=1.63 \%$

o Tingkat pengembalian harga saham BMRI 2 Januari 2006 $=\mathrm{LN}(1920 / 1810)=5.90 \%$

o Tingkat pengembalian harga saham BBRI 2 Januari 2006 $=\mathrm{LN}(3350 / 3325)=0.75 \%$

o Tingkat pengembalian harga saham PGAS 2 Januari 2006 $=\mathrm{LN}(1840 / 1560)=16.51 \%$

o Tingkat pengembalian harga saham BBNI 2 Januari 2006 $=\mathrm{LN}(1390 / 1360)=-2.18 \%$

o Tingkat pengembalian IHSG 2 Januari 2006 $=\mathrm{LN}(255 / 325)=2.28 \%$ 
Tingkat pengembalian saham maupun pasar tersebut dihitung secara mingguan hingga 27 desember 2010 sesuai dengan data IHSG dengan perhitungan yang sama. Dari hasil perhitungan, dapat disimpulkan bahwa terjadi kenaikan harga saham TLKM, BMRI, BBRI, dan PGAS pada 9 Januari 2006 dibandingkan dengan minggu sebelumnya yaitu 2 Januari 2006 yang menyebabkan tingkat pengembalian bernilai positif yaitu masing-masing sebesar $1.63 \%, 5.90 \%, 0.75 \%$ dan $16.51 \%$. Untuk tingkat pengembalian saham BBNI mengalami penurunan sebesar $2.18 \%$, karena harga saham dari minggu pertama hingga minggu kedua Januari 2006 harga saham BBNI menurun dari harga Rp.1,390 menjadi Rp.1,360. Sedangkan untuk IHSG, tingkat pengembalian pasar (IHSG) naik sebesar 2.28\% yang artinya pasar saham secara keseluruhan sedang naik/baik. Untuk perhitungan dan penjelasan minggu selanjutnya sama dengan contoh sebelumnya, dan dilakukan sampai dengan 27 Desember 2010.

Langkah kedua, dilakukan perhitungan beta rata-rata $(\beta)$. Beta tersebut ditentukan berdasarkan tingkat pengembalian harga saham masing-masing 5 perusahaan BUMN dan IHSG. Beta dihitung dengan menggunakan fungsi Slope dalam Microsoft Excel. Adapun hasil perhitungan beta rata-rata $(\beta)$, ialah sebagai berikut.

Tabel 3 Hasil Penghitungan Beta Rata-rata

\begin{tabular}{lc}
\hline & $\begin{array}{c}\text { Beta }(\boldsymbol{\beta}) \\
=\end{array}$ \\
\hline TLKME $\left(\mathbf{R}_{\mathbf{i}}, \mathbf{R}_{\mathbf{M}}\right)$ \\
BMRI & $\mathbf{0 . 6 9 5 3 3 8 5 7 7}$ \\
BBRI & $\mathbf{1 . 1 9 3 2 4 3 0 4 3}$ \\
PGAS & $\mathbf{1 . 0 4 4 4 9 8 9 0 2}$ \\
BBNI & $\mathbf{1 . 0 0 2 5 1 0 8 8 3}$ \\
Rata-rata & $\mathbf{1 . 2 7 3 0 3 3 7 9 3}$ \\
\hline
\end{tabular}

Beta rata-rata yang dihasilkan yaitu sebesar 1.0417, yang artinya ukuran sensitivitas saham dari risiko pasar yang mengukur tingkat pengembalian saham bergerak terhadap saham. Karena beta yang diperoleh sama dengan 1 mengandung arti bahwa harga saham sefluktuatif dengan pasar atau sensitif atau agresif terhadap pasar saham. Apabila beta yang diperoleh kurang dari 1, harga saham tersebut akan tidak akan sensitif/bergerak mengikuti pasar. Dengan kata lain, makin besar nilai beta, makin besar pula risiko saham tersebut.

Langkah ketiga yang dilakukan setelah menghitung tingkat pengembalian pasar $\left(\mathrm{R}_{\mathrm{M}}\right)$ dan Beta rata-rata $(\beta)$ yaitu menghitung tingkat bunga BI (BI Rate) yang disimbolkan dengan RFR. Untuk BI rate, diasumsikan data yang digunakan adalah rata-rata dari BI rate tahun 2006 sampai 2010. Setelah memperoleh hasil dari perhitungan ketiga komponen biaya ekuitas, yaitu tingkat pengembalian pasar $\left(\mathrm{R}_{\mathrm{M}}\right)$, beta rata-rata $(\beta)$, dan BI rate (RFR), maka kita dapat menghitung biaya ekuitas dengan menggunakan CAPM. Perhitungan biaya ekuitas $\left(\mathrm{K}_{\mathrm{s}}\right)$, dapat dilihat pada tabel 4 berikut.

Tabel 4 Perhitungan Biaya Ekuitas

\begin{tabular}{lrr}
\hline & Mingguan & \multicolumn{1}{c}{ Tahunan } \\
\hline$R_{M}$ & $0.42 \%$ & $22.085 \%$ \\
$B$ & & 1.0417 \\
$R F R$ & & $8.55 \%$ \\
$K_{s}$ & & $22.65 \%$ \\
\hline
\end{tabular}


Adapun perhitungan CAPM tersebut adalah sebagai berikut.

$$
K_{s}=8.55 \%+(22.085 \%-8.55 \%) \times 1.0417=22.65 \%
$$

Biaya ekuitas $\left(\mathrm{K}_{\mathrm{s}}\right)$ yang diperoleh dengan menggunakan metode perhitungan CAPM untuk 2010 diperoleh hasil $22.65 \%$. Biaya ekuitas sebesar $22.65 \%$ menunjukkan besarnya biaya yang perlu dibayarkan kepada investor seperti deviden sebagai hasil dari pengembalian investasi mereka.

\section{Biaya Utang (Cost of Debt)}

Dalam penelitian ini, biaya utang dihitung dengan menggunakan Damodaran Spreedsheet. Dalam Damodaran Spreedsheet, dilihat default spread for country dan interest rate of bond berdasarkan bond rating Indonesia pada tahun 2010 yang dinilai oleh Standar \& Poor's yaitu BB. Untuk perhitungan biaya utang $\left(\mathrm{k}_{\mathrm{d}}\right)$ Garuda, penulis mengasumsikan bond rating Garuda sesuai dengan peringkat obligasi yang dinilai oleh Standar \& Poor's untuk Indonesia pada Maret 2010 yaitu BB. Adapun perhitungan biaya utang $\left(\mathrm{k}_{\mathrm{d}}\right)$ tersebut adalah sebagai berikut.

$$
K_{d}=6.5 \%+4.25 \%+7.75 \%=18.50 \%
$$

Dari hasil perhitungan, diperoleh biaya utang sebesar $18.50 \%$ yang artinya, tingkat suku bunga yang harus dibayarkan atas utang kepada lembaga pembiayaan yaitu sebesar $18.50 \%$.

\section{Pajak (Tax)}

Tarif pajak ini akan digunakan dalam perhitungan komponen biaya utang, yaitu biaya utang setelah pajak. Biaya utang akan menimbulkan biaya bunga yang menyebabkan penurunan penghasilan. Dengan demikian, utang dapat mengurangi pajak yang harus dibayar. Jadi, langkah berikut yang dilakukan adalah menentukan besarnya rata-rata persentase pajak selama periode 20062010.

Penulis akan menghitung tarif pajak dengan menggunakan rata-rata keseluruhan pajak yang dibayarkan perusahaan, dengan mengasumsikan perusahaan membayar pajak sesuai peraturan tarif pajak yang ditetapkan oleh Direktorar Jenderal Pajak untuk wajib pajak badan pada periode tersebut. Berikut ialah tabel tarif pajak selama periode 2006-2010.

Tabel 5 Tarif Pajak Periode 2006-2010

\begin{tabular}{lrcccc}
\hline & $\mathbf{2 0 0 6}$ & $\mathbf{2 0 0 7}$ & $\mathbf{2 0 0 8}$ & $\mathbf{2 0 0 9}$ & $\mathbf{2 0 1 0}$ \\
\hline Pajak (\%) & $30 \%$ & $30 \%$ & $30 \%$ & $28 \%$ & $25 \%$ \\
Rata-rata Pajak (\%) & $28.6 \%$ & & & & \\
\hline
\end{tabular}

\section{Weighted Average Cost of Capital (WACC)}

Biaya modal merupakan campuran yang berasal dari utang jangka panjang dan laba ditahan atau ekuitas. Data yang dibutuhkan untuk meghitung proporsi struktur modal perusahaan ialah laporan keuangan perusahaan dalam bentuk neraca (balance sheet) selama periode 2006-2010. Hasil dari komponen modal tersebut merupakan total keseluruhan sumber pendanaan yang dimiliki PT. Garuda Indonesia (Persero), Tbk. Berikut adalah proporsi struktur modal perusahaan dalam bentuk utang dan ekuitas. 
Tabel 6 Proporsi Struktur Modal PT. Garuda Indonesia (Persero), Tbk.

\begin{tabular}{|c|c|c|c|c|c|}
\hline & 2006 & 2007 & 2008 & 2009 & 2010 \\
\hline Jumlah Utang Jk. Panjang & $38,834,852,358$ & $31,522,862,585$ & $4,578,527,816,853$ & $1,015,868,855,215$ & $1,617,202,334,913$ \\
\hline Jumlah Ekuitas & $751,087,837,445$ & $1,829,180,464,887$ & $254,629,282,616$ & $3,214,070,614,401$ & $3,457,261,695,881$ \\
\hline Total & $789,922,689,803$ & $1,860,703,327,472$ & $4,833,157,099,469$ & $4,229,939,469,616$ & $5,074,464,030,794$ \\
\hline Bobot utang (Wd) & $4.92 \%$ & $49.31 \%$ & $94.73 \%$ & $24.02 \%$ & $31.87 \%$ \\
\hline Bobot ekuitas (Ws) & $95.08 \%$ & $50.69 \%$ & $5.27 \%$ & $75.98 \%$ & $68.13 \%$ \\
\hline Total & $100.00 \%$ & $100.00 \%$ & $100.00 \%$ & $100.00 \%$ & $100.00 \%$ \\
\hline
\end{tabular}

\begin{tabular}{lr} 
Rata-Rata proporsi & \\
Wd & $31.45 \%$ \\
Ws & $68.55 \%$ \\
Total & $100.00 \%$ \\
\hline
\end{tabular}

keterangan: data dibuat dalam satuan Rupiah

Perhitungan proporsi struktur modal perusahaan tahun 2006:

$\mathrm{W}_{\mathrm{d}} 2006=\operatorname{Rp} 38,834,852,358 / \mathrm{Rp} 789,922,689,803=4.92 \%$

$\mathrm{W}_{\mathrm{s}} 2006=\operatorname{Rp} 751,087,837,445 / \operatorname{Rp} 789,922,689,803=95.08 \%$

Setelah menentukan semua komponen WACC, yaitu rata-rata komponen biaya utang setelah pajak, biaya ekuitas, biaya utang dan proporsi struktur modal perusahaan selama periode 2006-2010, maka sudah dapat menghitung WACC tahun 2010.

Perhitungan WACC tersebut ialah sebagai berikut:

$$
W A C C=\{[31.45 \% \times(18.50 \% \times(1-28.6 \%))]\}+(68.55 \% \times 22.65 \%)=19.68 \%
$$

\section{Perhitungan Free Cash Flow to the Firm (FCFF)}

Free cash flow to firm (FCFF) akan mencerminkan kas yang benar-benar tersedia untuk didistribusikan kepada para investor dan perhitungan ini lebih relevan untuk digunakan ketika mengestimasikan nilai dari suatu perusahaan. Nilai dari operasi sebuah perusahan akan bergantung pada seluruh arus kas bebas yang diharapkan di masa mendatang. Oleh karena itu, penulis melakukan perhitungan arus kas bebas (FCFF), yang kemudian akan dikombinasikan dengan biaya modal ratarata tertimbang (WACC) untuk menentukan estimasi harga wajar saham

\section{Peramalan Pendapatan Garuda pada 2011}

Pendapatan Garuda pada 2011 dapat kita hitung dengan memasukkan data pendapatan Garuda yang terdapat di laporan keuangan periode 2006-2010 dengan menggunakan fungsi forecast yang ada di Microsoft Excel, dimana tahun 2011 merupakan tahun ke-6. Perkiraaan pendapatan Garuda ini, akan digunakan dalam memperkirakan FCFF pada 2011 dan selanjutnya dapat melihat harga IPO harga saham Garuda.

Perkiraan pendapatan Garuda di tahun 2011 ialah sebagai berikut:

Estimasi Pendapatan 2011= FORECAST (Tahun ke 6;SALES2006-2010;Tahun ke1-5)

$$
=\operatorname{Rp} 22,079,155,588,187
$$


Berdasarkan perhitungan tersebut, diperkirakan nilai estimasi revenue tahun 2011 sebesar Rp.22,079,155,588,187. Artinya, estimasi revenue meningkat dari tahun sebelumnya yaitu sebesar Rp.19,534,331,480,504 pada 2010, karena estimasi dihitung dengan menggunakan percentage of sales method (PSM) dari rata-rata tahun historis yang fluktuatif.

\section{Perkiraan FCFF 2011}

Dalam memperkirakan FCFF tahun 2011, maka penulis juga melakukan peramalan untuk masing-masing komponen FCFF, yaitu EBIT (1-Tax Rate), depreciation and amortization expense, capital expenditures (capex), dan change in working capital. Masing-masing komponen FCFF dihitung dengan cara percentage of sales method. Berikut ini ialah contoh perhitungan PSM EBIT (1T), PSM depreciation and amortization, dan PSM Capital Expenditure, tahun 2006:

PSM EBIT(1-T) $2006=\mathrm{Rp}-378726952161 / \mathrm{Rp} 12,343,167,640,539=-3.07 \%$

PSM Dep $2006=\operatorname{Rp} 352,250,797,710 / \mathrm{Rp} 12,343,167,640,539=2.85 \%$

PSM CAPEX $2006=\operatorname{Rp} 41,730,323,035 / \mathrm{Rp} 12,343,167,640,539=0.34 \%$

$\mathrm{PSM} \triangle \mathrm{WC} 2006=0 \%$

Khusus untuk working capital, dalam FCFF digunakan perubahannya ( $\Delta$ WC), maka $\Delta$ PSM WC 2006 belum dapat diketahui. Baru pada 2007 perubahan working capital dapat dihitung. Working Capital yang digunakan dalam perhitungan FCFF ini yaitu non-cash working capital yang komponennya terdiri dari piutang usaha, persediaan, dan utang usaha.

Begitu pula dengan perhitungan periode 2007-2010. Hasil dari masing-masing persentase PSM yang diperoleh kemudian dihitung rata-ratanya dengan menggunakan fungsi Average pada Microsoft Excel, dengan perhitungan sebagai berikut:

PSM EBIT(1-t) 2011=Average(-3.07\%,0.83\%,4.28\%,3.70\%,-0.34\%) $=1.08 \%$

PSM Dep2011 =Average $(2.85 \%, 2.43 \%, 2.14 \%, 9.01 \%, 8.44 \%)=4.97 \%$

PSM CAPEX $2011=$ Average $(0.34 \%, 3.86 \%, 1.74 \%, 4.18 \%, 1.97 \%)=2.42 \%$

PSM $\Delta$ WC $2011=$ Average $(0.35 \%,-1.81 \%, 6.23 \%, 1.48 \%)=1.56 \%$

Setelah diperoleh rata-rata percentage of sales method masing-masing komponen, dapat dihitung estimasi komponen EBIT(1-T), depreciation and amortiation, capital expenditure, dan change in working capital untuk 2011 dengan revenue forecast yang telah dihitung sebelumnya. Berikut perhitungan estimasi masing-masing komponen tahun 2011:

EBIT(1-T) $2011=\mathrm{Rp} 22,079,155,588,187 \times 1.08 \%=\mathrm{Rp} 238,770,298,073$

Dep $2011=\operatorname{Rp} 22,079,155,588,187 \times 4.97 \%=R p 1,098,262,404,395$

CAPEX $2011=\operatorname{Rp} 22,079,155,588,187$ x2.42\% $=$ Rp 533,661,294,031

$\Delta \mathrm{WC} 2011=\operatorname{Rp} 22,079,155,588,187 \times 1.56 \%=-\operatorname{Rp} 344,792,400,785.240$

Berdasarkan estimasi masing-masing komponen FCFF yang telah dilakukan, maka estimasi FCFF untuk tahun 2011 sebesar Rp.458,579,007,651.459, dengan perhitungan estimasi FCFF adalah sebagai berikut:

$\mathrm{FCFF}=\mathrm{Rp} 238,770,298,073.189+\mathrm{Rp} 1,098,262,404,395.590-$

Rp 533,661,294,031.083 - Rp 344,792,400,785.240

$=\operatorname{Rp} 458,579,007,651.459$ 


\section{Estimasi Nilai Intrinsik Saham}

Estimasi harga wajar saham PT. Garuda Indonesia (Persero), Tbk. pada 2011 dapat dihitung dengan mengurangi nilai perusahaan dengan nilai utang sehingga menghasilkan nilai ekuitas. Dimana, nilai perusahaan tersebut dihitung dengan cara FCFF tahun 2011 dibagi dengan pengurangan WACC dengan tingkat pertumbuhan ekonomi Indonesia. Kemudian, nilai ekuitas tersebut dibagi dengan jumlah saham yang beredar, dan hasil inilah yang merupakan nilai wajar saham Garuda pada akhir 2011 yang akan dibandingkan dengan harga saham IPO Garuda. Perhitungan nilai perusahaan tersebut ialah:

$$
\begin{aligned}
\text { Value of Firm } & =\operatorname{Rp} 458,579,007,651.459 /(19.68 \%-6.5 \%) \\
& =\operatorname{Rp} 3,479,142,512,583.61
\end{aligned}
$$

Setelah menghitung nilai dari perusahaan tersebut, selanjutnya yaitu menghitung nilai ekuitas. Nilai ekuitas tersebut dihitung dengan cara nilai perusahaan dikurangi dengan rata-rata dari total utang jangka panjang yaitu:

$$
\begin{aligned}
\text { Total Equity } & =\operatorname{Rp} 3,479,142,512,583.61-\operatorname{Rp~1,456,391,344,385~} \\
& =\operatorname{Rp} 2,022,751,168,198.81
\end{aligned}
$$

Dengan mengetahui total equity dengan perhitungan tersebut, nilai estimasi harga wajar saham (intrinsik value) perusahaan sudah dapat dihitung. Nilai harga saham tersebut dapat diperoleh dengan membagi nilai ekuitas dengan jumlah saham yang beredar. Perhitungan nilai instrinsik tersebut ialah:

$$
\text { Intrinstk Value 2011 }=\frac{R p 2,022,751,168,198.81}{6,335,738,000}=R p 319.26
$$

Berdasarkan perhitungan diatas, estimasi harga wajar saham Garuda pada 2011 adalah sebesar Rp.319.26. Dari hasil estimasi harga wajar saham tersebut dibandingkan dengan harga pasar untuk dinilai apakah harga saham IPO Garuda dinilai overvalued atau undervalued. Telah diketahui harga saham Garuda ketika IPO yaitu Rp.750.

Dari perbandingan nilai intrinsik dengan nilai pasar saham yang diketahui, dapat dilihat bahwa penilaian harga saham Garuda pada saat IPO dinilai overvalued yaitu nilai intrinsik lebih kecil daripada harga pasar.

\section{SIMPULAN}

Berdasarkan analisis dan pembahasan yang dilakukan, maka penilaian bisnis terhadap PT. Garuda Indonesia (Persero), Tbk. dapat disimpulkan, pertama, berdasarkan analisis SWOT, bahwa: Garuda memiliki kekuatan sebagai maskapai penerbangan terbesar yang memiliki brand yang memiliki teknologi informasi canggih, dengan tim yang handal dan kompeten serta menempatkan pelanggan sebagai fokus utama dalam pelayanan; Garuda mempunyai kelemahan seperti adanya faktor teknis yaitu keterbatasannya jumlah cockpit dan cabin crew yang dapat menghambat ketepatan penerbangan, bergantungnya Garuda terhadap sistem otomatisasi, tingginya utang lancar karena peningkatan opersional yang tinggi dan menyebabkan biaya tiket yang mahal; Garuda juga memliki peluang yang dapat menguntungkan Garuda seperti pertumbuhan penumpang penerbangan di Indonesia yang pesat, bergabungnya Garuda sebagai anggota aliansi global serta telah dikeluarkannya Garuda Indonesia dari daftar perusahaan penerbangan yang dilarang terbang di kawasan Eropa. 
Dengan peluang tersebut Garuda dapat meningkatkan jaringan penerbangannya; dan selain memiliki peluang, Garuda juga memiliki ancaman, ancaman tersebut ialah adanya faktor fasilitas bandara seperti landasan pacu yang terbatas, faktor-faktor alam yang tidak dapat diduga, sumber pasokan bahan bakar yang hanya tersedia pada satu supplier, banyaknya peningkatan kapasitas oleh maskapai penerbangan lain dan maskapai asing yang melakukan penetrasi ke Indonesia.

Kedua, berdasarkan analisis Porter, dapat disimpulkan bahwa persaingan di dalam industri penerbangan cenderung tinggi, yang dapat dilihat sebagai berikut.

Tabel 7 Simpulan Berdasarkan Analisis Porter

\begin{tabular}{|c|c|c|c|c|}
\hline \multirow[t]{2}{*}{ Kekuatan } & \multicolumn{3}{|c|}{ Tingkat Kekuatan } & \multirow[b]{2}{*}{ Cara Menanggulangi } \\
\hline & High & Medium & Low & \\
\hline $\begin{array}{l}\text { Persaingan } \\
\text { antarperusahaan saingan }\end{array}$ & $\sqrt{ }$ & & & $\begin{array}{l}\text { Melakukan penambahan pesawat, } \\
\text { rute penerbangan, dan bergabung ke } \\
\text { dalam aliansi global }\end{array}$ \\
\hline $\begin{array}{l}\text { Potensi masuknya pesaing } \\
\text { baru }\end{array}$ & & $\sqrt{ }$ & & $\begin{array}{l}\text { Meningkatkan pelayanan dan } \\
\text { menjaga kesetiaan konsumen } \\
\text { (program GFF) }\end{array}$ \\
\hline $\begin{array}{l}\text { Potensi pengembangan } \\
\text { produk-produk pengganti }\end{array}$ & & $\sqrt{ }$ & & $\begin{array}{l}\text { Memberikan potongan harga dan } \\
\text { full service }\end{array}$ \\
\hline Daya Tawar Pemasok & $\sqrt{ }$ & & & $\begin{array}{l}\text { Melakukan negosiasi dengan } \\
\text { Pertamina }\end{array}$ \\
\hline Daya Tawar Konsumen & $\sqrt{ }$ & & & Membuat unit bisnis citilink \\
\hline
\end{tabular}

Dan terakhir, ketiga, berdasarkan analisis free operating cash flow to firm (FCFF) harga saham PT. Garuda Indonesia (Persero), Tbk. pada saat IPO tersebut overvalued.

\section{DAFTAR PUSTAKA}

Badan Pusat Statistik. (2011). Berita resmi statistik. http://www.bps.go.id/brs file/pdb-05mei11.pdf. Diakses tanggal 22 Mei 2011.

Bank Indonesia. http://www.bi.go.id/web/id/. Diakses tanggal 22 Mei 2011.

Brigham, E. F., \& Houston, J. F. Alih bahasa oleh Yulianto, A. A. (2006). Dasar-dasar manajemen keuangan (edisi 10). Jakarta: Salemba Empat.

Brown, K. C., \& Reilly, F. K. (2009). Analysis of Investments and Management of Portfolios ( $9^{\text {th }}$ ed.). United States: South-Western Cengage Learning.

Damodaran, A. (2006). Damodaran on Valuation: Security Analysis for Investment and Corporate Finance $\left(2^{\text {nd }}\right.$ ed. $)$. United States: John Wiley \& Sons.

Darmadji, T., \& Fakhruddin, H. M. (2006). Pasar Modal di indonesia - Pendekatan Tanya Jawab (edisi 2). Jakarta: Salemba Empat.

Darsono \& Ashari. (2005). Pedoman Praktis Memahami Laporan Keuangan (edisi 1). Yogyakarta: ANDI.

David, F. R. Alih bahasa oleh Sunardi, D. (2009). Manajemen Strategis Konsep (edisi 12). Jakarta: Salemba Empat. 
Fakhruddin, H. M. (2008). Istilah Pasar Modal a-z. Jakarta: Elex Media Komputindo.

Fernandez, P. (2007). Valuing Companies by Cash Flow Discounting: Ten Methods and Nine Theories. Journal of Accounting Research, 33(11): 853-876.

Gibson, C. H. (2009). Financial Reporting \& Analysis: Using Financial Accounting Information $\left(11^{\text {th }}\right.$ ed.). Mason: South-Western Cengage Leraning.

Goldberg, J. L. (2009). The Valuation of Toll Roads and The Implication For Future Solvency with Special Reference to the Transurban Group. Journal of Business Valuation and Economic Loss Analysis, 4(1): 2.

Hunger, J. D., \& Thomas L. W. Alih bahasa oleh Agung Julianto (2003). Manajemen Strategis (edisi 5). Yogyakarta: Andi.

Kementerian Perhubungan Republik Indonesia. (2010). Pengaju izin pendirian maskapai baru berguguran. $\quad$ http://www.dephub.go.id/read/berita/direktorat-jenderal-perhubunganudara/2448. Diakses tanggal 15 Mei 2010.

Lane, M. A. (2002). Business Finance Online. http://www.zenwealth.com/BusinessFinanceOnline/FF/percentageOfSales.html. Diakses tanggal 9 Juni 2011.

Munawir. (2004). Analisa laporan keuangan. Edisi Keempat. Yogyakarta: Liberty.

Stowe, J. D., Robinson, T. R., Pinto, J. E., \& Mcleavey, D. W. (2007). Equity asset valuation. Hoboken, New Jersey: John Wiley \& Sons.

Sugiono, A. (2008). Manajemen Keuangan untuk Praktisi Keuangan. Jakarta: Grasindo.

Tandelilin, E. (2010). Portofolio dan Investasi: Teori dan Aplikasi (edisi 1). Yogyakarta: Kanisius.

Undang-Undang RI No. 36 Tahun 2008, Tentang Perubahan keempat atas undang-undang no.7 tahun 1983 tentang pajak penghasilan.

Undang-Undang RI No. 17 Tahun 2000, Tentang Perubahan ketiga atas undang-undang no. 7 tahun 1983 tentang pajak penghasilan.

Van Horne, J. C. Wachowicz, John M. Alih bahasa Fitriasari Dewi \& Kwary Deny Arnos. (2001). Prinsip-prinsip Manajemen Keuangan (edisi 12). Jakarta: Salemba Empat.

Weygandt, J. J., Kieso, D. E., \& Kimmel, P. D. (2005). Accounting Principles (7 ${ }^{\text {th }}$ ed.). United States: John Wiley \& Sons.

Yahoo Finance. http://finance.yahoo.com. Diakses tanggal 31 Mei 2011. 